\title{
Adoption of big data technologies in smart cities of the European Union: Analysis of the importance and performance of technological factors
}

\author{
Jasmina Pivar \\ University of Zagreb Faculty of Economics and Business
}

\begin{abstract}
The cities of the European Union are adopting big data technologies in their development towards a smart city. Given that big data technologies are complex and disruptive technologies, it is necessary to determine the importance of factors and their aspects for the adoption of big data technologies in cities. The aim of this paper is to identify the most important aspects of technological factors in the adoption of big data technologies in the cities of the European Union. In order to achieve the goal of the paper a survey was conducted on a sample of European Union cities, and on the collected data, an analysis of the map of importance and performance of factors for the adoption of big data technologies was conducted. The results of the research show that the aspects of absorption capacity and technological readiness of EU cities are of relatively high importance, but with low levels of performance in relation to organizational and environmental factors. The contribution of the paper consists of general guidelines for increasing the level of technological readiness and absorption capacity of cities in order to increase the success of the adoption of big data technologies in the cities of the European Union.
\end{abstract}

Keywords: smart cities, European Union, technology adoption, big data technologies, absorption capacity, technological readiness, IPMA

Type of paper: research article

Received: $12 / 11 / 2020$

Accepted: $1 / 8 / 2021$

DOI: $10.2478 / \mathrm{crdj}-2021-0005$

\section{Introduction}

In smart cities, information and communication technology play an important role. The information and process view of cities describes smart cities as "sophisticated systems in which a large amount of data is processed in real time and integrated into processes, systems, organizations and value chains in order to optimize operations and inform authorities about problems" (Neirotti, 2014). The adoption of technologies should start from the needs of citizens, other stakeholders, and public problems that need to be solved, so that technologies will not be used in the same way in all cities. Therefore, for the purpose of this article, a smart city is considered one that "seeks to solve public problems through solutions based on information and communication technologies with the joint support of 
several stakeholders and local authorities" (European Parliament Committee on Industry, Research and Energy, 2014). Thus, the selection and application of information and communication technology in a particular city depends on its needs and environment.

Big data technologies are a web of information and communication technologies for the creation, adoption, storage, processing, and analysis of large amounts of data. They can be considered as innovative information and communication technologies given that in many cities, they are in the process of adoption or are completely new and their adoption is being considered. Companies in European Union countries have largely started to use large data for smart business purposes (Pejić Bach et al., 2020). Big data is often part of digital business transformation initiatives (Tomičić Furjan, Tomičić-Pupek and Pihir, 2020). In large data, knowledge and information are found that are used in decision making, and it is possible to use different methods and techniques of data analysis such as text mining (Pejić Bach et al., 2019) and various new methods for prediction (Pejić Bach, Pivar and Krstić , 2019). Big data technologies in cities are used to improve different areas of the city (Hashem, 2016; Bettencourt, 2013). They enable the application of different smart solutions in different areas of the city's infrastructure. In order to achieve the desired effects of the adoption of information and communication technologies in the city, the city management and stakeholders should jointly actively manage and participate in the development of the smart city (Bolívar, 2015). However, the adoption of complex technologies such as big data technologies is a challenge for cities. For this reason, it is important to know what factors are important for their adoption in the city, and the current performance of important factors.

The aim of this paper is to answer the question of which aspects of technological factors are important for the adoption of big data technologies in the cities of the European Union. In order to achieve the goal of the research, data were collected through a survey on a sample of European Union cities. Based on the collected data, the main research model was first evaluated using the Partial Least Squares Structural Equation Modelling (PLSSEM) method. Following the PLS-SEM assessment, an Importance-Performance Map Analysis (IPMA) was conducted to compare the importance and performance of independent technological factors and their aspects for the adoption of big data technologies in the European Union cities. The paper is a continuation of the research conducted for the purpose of the doctoral dissertation in which the model of adoption of big data technologies in the cities of the European Union is evaluated (Pivar, 2020a). Since IPMA is based on the results of model evaluation, this paper contains a summary of the key results of model evaluation from the mentioned doctoral dissertation. The research is a supplement to existing research on the factors of the organization and environment of the adoption of big data technologies in EU cities (Pivar and Vlahović, 2020; Pivar, 2020b). The contribution of the paper is reflected in the explanation of the importance and performance of technological factors of big data technology adoption in European Union cities, as previous research has looked at big data adoption factors or big data analytics at the organization level (Cegielski, Jia and Hall, 2018; Lai, Sun and Ren, 2018; Chen, Preston, and Swink, 2015).

After the Introduction, the paper contains a review of the literature and the development of hypotheses in which the model on which this paper is based is described and the technological factors are explained. After that, the chapter Methodology describes the research instrument, data, and the method of analysis of importance and performance. The Results chapter contains the results of the measurement and structural assessment of the main model, followed by the results of the analysis of importance and performance. Discussion and Conclusion follow at the end. 


\section{Literature review and hypothesis development}

The existing technological infrastructure significantly affects the diffusion of technology in the organization (Tornatzky, Fleischer, and Chakrabarti, 1990). The technological infrastructure of an organization consists of the existing computer hardware, software, and network technologies of the organization needed to implement new information and communication technologies (Bhattacherjee and Hikmet, 2008). In addition to technological infrastructure, IT human resources (Zhu, Kraemer and Xu, 2006) and technological competencies as part of the organizational capacity for information technology-based innovations can be included in the technological readiness factor (Sambamurthy, Bharadwaj and Grover, 2003). Organizations are more likely to adopt innovative information and communication technologies if they have developed aspects of technological readiness (Wang and Lo, 2016; Dedrick et al., 2015).

Organizational readiness influences the decision to adopt an innovation (Tsai and Tang, 2012). The notion of organizational readiness combines management's perception of the degree of awareness of new information and communication technologies, the possession of resources and management skills, and the organization's commitment needed to adopt innovative information and communication technologies (Tan, Tyler, \& Manica, 2007). Organizational readiness, in addition to technological readiness, also includes financial readiness, which consists of the financial resources needed to invest in new technologies (Rouhani et al., 2018).

For the purpose of the research, technological readiness was described through technological infrastructure, technological expertise, and financial resources, and hypothesis H1a was set:

H1a: Technological readiness has a statistically significant positive effect on the adoption of big data technologies in cities.

Absorption capacity was originally used to describe the social capacity of developing countries, but at the organizational level, absorption capacity describes the ability to acquire new knowledge that depends on the absorption capacity of members of the organization (Cohen and Levinthal, 1990).

Adopting big data technology as a risky disruptive innovation requires the absorption capacity of the city to recognize the potential value of introducing big data technologies into the city's infrastructure. The absorption capacity of the city is determined by the experiences of the city gained by the previous adoption of various information and communication technologies. Although absorption capacity has been used in different contexts and at different levels of analysis, there are only a few studies in which some aspects of absorption capacity have been used in ICT adoption models, for example in Rouhani et al. (2018) and Weia, Lowry and Seedorf (2015). The absorption capacity for the purposes of the main research has been reduced to the level of the city and implies the ability of the city to recognize the value of new, external knowledge, assimilate it and use it for various purposes. The hypothesis that assumes a direct positive impact of absorption capacity on the adoption of big data technologies in cities is:

$H 1 b$ : The absorption capacity has a statistically significant positive effect on the adoption of big data technologies in cities.

According to innovation diffusion theory, compatibility is the degree to which an innovation is perceived as consistent with existing values, past experiences, and the need of potential adopters (Rogers, 2003). Organizations that perceive technology more compatible with existing beliefs and work practices have a greater predisposition to adopt new technologies successfully. 
Compatibility has been used in models of adoption of different technologies in different industries, but research has shown that it is a significant factor in some examples of adoption of cloud computing (Gutierrez, Boukrami and Lumsden, 2015; Abdollahzadehgan et al., 2013) and RFID technology (Wang, Wang and Yang, 2010). For the purpose of this research, big data compatibility is defined as the degree to which big data technologies are perceived as consistent with existing infrastructure, practices, and city needs. The hypothesis of the main research model related to the impact of compatibility on the adoption of big data technologies in cities is:

H1C: Compatibility has a statistically significant positive effect on the adoption of big data technologies in cities

\section{Methodology}

This chapter explains the methodology used to conduct the main research and then the method of importance and performance analysis used to meet the objective of the paper.

\section{Model of adoption of big data technologies in the cities of the European Union}

This research is based on the analysis of the results of the evaluation of a broader research model of the adoption of big data technologies in the cities of the European Union. The model is based on The Technology-Organization-Environment Framework (TOE). The TOE framework was developed by Tornatzky, Fleischer, and Chakrabarti (1990) with the aim of explaining the process of adopting innovation in the business of organizations. According to the TOE framework, the adoption of a certain innovative information and communication technology is influenced by a specific set of factors of technology, organisation, and environment.

The TOE framework is used to explain the adoption of a number of innovative information and communication technologies, so the TOE framework was the basis for conceptualizing the model of adoption of big data technologies in the cities of the European Union. For research purposes, a dependent factor of the research model is called Adoption of Big Data in Cities (AT) and is described as a process of acceptance, integration, and use of big data in cities. The focus of this research is the independent factors of the technological context Absorption Capacity (AC), Technological Readiness (TR) and Compatibility (CM). The main research hypothesized the direct positive impact of technological factors on the adoption of big data technologies in the cities of the European Union. It is assumed that technological readiness has a positive effect on the adoption of big data technologies in cities ( $\mathrm{H} 1 \mathrm{a})$, as well as absorption capacity ( $\mathrm{H} 1 \mathrm{~b})$ and compatibility $(\mathrm{H} 1 \mathrm{c})$.

Additional independent factors of the broader research model are the organizational factors Existence of a Smart City Strategy (SCS) and City Management Support (CMS) and Stakeholder Support (SS) as an environmental factor. Although organizational and environmental factors are not in focus, they need to be included in the results of the main model assessment and used to compare with technological factors.

\section{Research instrument}

Data collection for the assessment of the main research model was conducted using a structured survey questionnaire. The particles used in the questionnaire were created or adapted based on existing literature. Each factor was measured using four particles on the Likert scale at an interval of one to seven. 
The questionnaire was divided into 4 parts. In the first part, the particles of technological factors were measured. Particles for measuring technological readiness (TR) were independently defined, while particles for measuring absorption capacity were taken and adapted according to Flatten et al. (2011), and the particles for measuring compatibility were adapted according to Gangwar, Date, and Ramaswamy (2013) and Chong and Chan (2012). In the second part, organizational factors were measured. Particles for measuring city management support were taken and adapted according to Oliveira, Manoi and Espadanal (2014) and ITU-T Focus Group on Smart Sustainable Cities (2015), while particles for measuring the existence of smart city strategy were developed according to the review of smart city strategy characteristics (Angelidou, 2014). The third part of the questionnaire measured stakeholder support as an environmental factor for which particles were developed according to the smart city stakeholder review (ITU-T Focus Group on Smart Sustainable Cities, 2015). In the first part, the dependent factor of the adoption of big data technologies in the cities of the European Union for which the particles are independently defined was measured. Details of the research instrument are shown in Table 1.

\section{Table 1}

Research instrument

\begin{tabular}{|c|c|c|c|}
\hline & Factors & $\begin{array}{l}\text { Particle } \\
\text { s }\end{array}$ & Claim \\
\hline & $\begin{array}{l}\text { Independent } \\
\text { factors }\end{array}$ & Code & $\begin{array}{l}\text { Please indicate to what extent you agree/disagree with the following } \\
\text { statements. ( } 1=1 \text { completely disagree, } 7=(\text { completely agree) }\end{array}$ \\
\hline \multirow{12}{*}{ 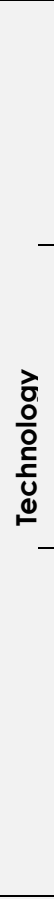 } & \multirow{4}{*}{$\begin{array}{l}\text { Technological } \\
\text { Readiness (TR) }\end{array}$} & TR1 & The city employs human resources with analytical skills. \\
\hline & & TR2 & $\begin{array}{l}\text { The city employs human resources with IT skills and skills in using programming } \\
\text { languages, technologies, and data-related programs. }\end{array}$ \\
\hline & & TR3 & $\begin{array}{l}\text { The city has a physical ICT infrastructure that can be upgraded with current big } \\
\text { data technologies and related technologies. }\end{array}$ \\
\hline & & TR4 & $\begin{array}{l}\text { The city management is aware of the costs and benefits of investing in } \\
\text { technology and has the financial means to upgrade the city with technology. }\end{array}$ \\
\hline & \multirow{4}{*}{$\begin{array}{l}\text { Absorption } \\
\text { Capacity (AC) }\end{array}$} & $\mathrm{ACl}$ & $\begin{array}{l}\text { City employees are motivated to use available data sources related to the } \\
\text { services the city currently provides. }\end{array}$ \\
\hline & & $\mathrm{AC2}$ & $\begin{array}{l}\text { City departments are aware of the importance of mutual assistance in solving } \\
\text { problems, and there is a rapid flow of information between them. }\end{array}$ \\
\hline & & AC3 & $\begin{array}{l}\text { City employees absorb new knowledge, connect existing knowledge with new } \\
\text { knowledge, use it in practical work, and make it available for future use. }\end{array}$ \\
\hline & & $\mathrm{AC} 4$ & $\begin{array}{l}\text { There is an awareness of new technologies in the city and they are regularly } \\
\text { considered and adopted to make city services more efficient. }\end{array}$ \\
\hline & \multirow{4}{*}{$\begin{array}{l}\text { Compatibility } \\
\text { (CM) }\end{array}$} & CM1 & $\begin{array}{l}\text { VP technologies are compatible with the existing technological infrastructure of } \\
\text { the city and can be seamlessly integrated into the existing tech. city } \\
\text { infrastructure. }\end{array}$ \\
\hline & & CM2 & $\begin{array}{l}\text { The changes brought about by the development of VP technologies are } \\
\text { consistent with the existing practices and experiences of the city with the } \\
\text { implementation of similar technologies. }\end{array}$ \\
\hline & & CM3 & $\begin{array}{l}\text { The changes and benefits brought by the implementation of VP technologies } \\
\text { are consistent with the needs of the city. }\end{array}$ \\
\hline & & CM4 & $\begin{array}{l}\text { VP technologies are compatible with the existing infrastructure, practices and } \\
\text { needs of the city. }\end{array}$ \\
\hline \multirow{6}{*}{ 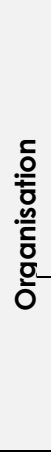 } & \multirow{4}{*}{$\begin{array}{c}\text { City } \\
\text { Management } \\
\text { Support (CMS) }\end{array}$} & CMS1 & $\begin{array}{l}\text { The city management provides strong leadership and is committed to } \\
\text { technology adoption processes in the city. }\end{array}$ \\
\hline & & CMS2 & $\begin{array}{l}\text {... promotes technology initiatives, determines implementation steps and } \\
\text { selects specific technology solutions to be implemented. }\end{array}$ \\
\hline & & CMS3 & $\begin{array}{l}\ldots \text { is ready to accept financial and organizational risks related to technology } \\
\text { adoption. }\end{array}$ \\
\hline & & CMS4 & $\begin{array}{l}\ldots \text { involves citizens in technological innovation efforts and communicates to } \\
\text { them about the benefits of technology. }\end{array}$ \\
\hline & \multirow{2}{*}{$\begin{array}{l}\text { Existence of } \\
\text { Smart City } \\
\text { Strategy (SCS) }\end{array}$} & SCS1 & $\begin{array}{l}\text { Based on the challenges related to city infrastructure and the needs of the city, } \\
\text { the city management is actively developing strategies aimed at improving the } \\
\text { efficiency of city resource management. }\end{array}$ \\
\hline & & SCS2 & $\begin{array}{l}\text { The city's strategy is focused on the efficiency and technological progress of } \\
\text { the "hard" infrastructure of the city. }\end{array}$ \\
\hline
\end{tabular}




\begin{tabular}{|c|c|c|}
\hline & SCS3 & $\begin{array}{l}\ldots \text { is focused on the efficiency and technological progress of the "soft" } \\
\text { infrastructure of the city. }\end{array}$ \\
\hline & SCS4 & $\begin{array}{l}\text { The city strategy is in line with the goals and strategy of the country and/or the } \\
\text { European Union related to the technological development of cities. }\end{array}$ \\
\hline & SS 1 & $\begin{array}{l}\text { There are stakeholders who enable technology and technological solutions } \\
\text { related to the adoption of technologies in the city. }\end{array}$ \\
\hline Stakeholder & SS2 & $\begin{array}{l}\text { There are stakeholders interested in launching technology adoption initiatives } \\
\text { in the city. }\end{array}$ \\
\hline Support (SS) & SS3 & $\begin{array}{l}\text { Citizens and civic organizations support or participate in technology adoption } \\
\text { initiatives in the city. }\end{array}$ \\
\hline & SS4 & $\begin{array}{l}\text { There are institutionalized stakeholders who provide the resources, assistance, } \\
\text { and frameworks for technology adoption in cities. }\end{array}$ \\
\hline Dependent factors & & \\
\hline & AT1 & $\begin{array}{l}\text { The city collects large amounts of structured, semi-structured and unstructured } \\
\text { data from a variety of sources. }\end{array}$ \\
\hline Adoption of big & AT2 & $\begin{array}{l}\text { The city has adopted the infrastructure and platforms needed to discover } \\
\text { knowledge from the VP. }\end{array}$ \\
\hline in cities (AT) & AT3 & $\begin{array}{l}\text { The city has adopted VP technologies with the aim of improving the "hard" } \\
\text { infrastructure of the city. }\end{array}$ \\
\hline & AT4 & $\begin{array}{l}\text { The city has adopted VP technologies with the aim of improving the "soft" } \\
\text { infrastructure of the city. }\end{array}$ \\
\hline
\end{tabular}

Source: Flatten et al. (2011); Gangwar et al. (2013); Chong and Chan (2012); Oliveira, Manoj and Espadanal (2014); ITU-T Focus Group on Smart Sustainable Cities (2015); Angelidou (2015) and adapted according to Pivar (2020a)

\section{Data}

In order to collect the data that were the basis for the assessment of the research model, a survey was conducted in the period from June 2017 to March 2018.

The target population of the research are the cities of the European Union member states (EU28). The research included cities with 40,000 or more inhabitants. The target population was a total of 1481 cities. The target respondents of the research were members of senior management in the city, including mayors, managers of the city's IT departments, chief information officers, and smart city initiative leaders. One respondent is attached to each city. The questionnaire was successfully sent to 1100 cities. A total of 110 partially or fully completed questionnaires were received, and a sample of data collected from 67 cities in the European Union was used for further analysis.

\section{Importance and performance map analysis}

In order to evaluate the main research model, the method of modelling the structural equations of partial least squares (Partial Least Squares Structural Equation Modelling PLS-SEM) with the support of SmartPLS3 software was used. SEM - PLS was used in a series of studies where a model of adoption of various technologies based on the TOE framework was tested. The evaluation of the main model was performed according to the evaluation steps of the PLS-SEM model proposed in Hair et al. (2017).

After evaluating the PLS-SEM model, it is possible to perform Importance-Performance Map Analysis (IPMA). The IPMA method compares the importance and performance of independent factors and their indicators in predicting the target dependent factor. The implementation of the assessment of the main model is a necessary precondition for the implementation of IPMA because it uses the results of the assessment of the measurement and structural model of the research. 
The importance of factors in PLS-SEM models is represented by the values of the total effects consisting of direct and indirect effects on the target factor and range from -1 to +1 . The closer the value is to one the higher the importance of the factor. If a factor has only a direct influence on the target factor, as in this paper, then the importance of independent factors is equal to their direct effects. In other words, the importance of the factors in this case is equal to the path coefficients.

The performance values of factors and indicators are calculated based on the values of their particles. The calculation begins by calculating the scaled values of all particles for each of the observations. The scaling of the observation $j$ to the particle $j$ is calculated as:

\section{Equation 1}

Scaling of the observation $j$ towards the particle $i$

$$
x_{i j}^{\text {scaled }}=\frac{E\left[x_{i j}\right]-\min \left[x_{i}\right]}{\max \left[x_{i}\right]-\min \left[x_{i}\right]} \times 100
$$

Source: according to Hair et al. $(2018$, p. 110$)$

where $x_{-} i$ is the $i$-th particle in the PLS model, $E\left[x_{-} i\right]$ is the actual value assigned to the $i$ th particle by the respondent $j$, and $\min []$ and $\max []$ are the minimum and maximum value that a particle can take (Hair et al., 2018, p. 110). For example, if the particles are measured by the Likert scale in the range of 1 to 7 then the minimum value is 1 and the maximum is 7. The value that the scaled value can take is in the range of 0 to 100 .

According to Hair et al. (2018) calculated scaled particle values by observations are used to calculate scaled factor values that represent factor performance, but also to calculate particle performance. The particle performance calculation is calculated as the mean of the calculated scaled particle values for all observations, and the scaled factor values are calculated as a linear combination of scaled particle values and scaled external particle weights. The higher the calculated values, the higher the performance of the factors or particles.

Furthermore, the values of the importance of the particles of a given factor are calculated by multiplying the scaled values of the external weights of the particles by the total effect that factor has on the target factor.

The aim of IPMA is to identify factors that are of relatively high importance in predicting the target factor, and at the same time have relatively low performance, which means that there is room for improvement in them. Based on the interpretation of the importance and performance map, the researcher can make concrete recommendations for improving certain aspects of factors that can increase the performance of target factors. Consequently, if it turns out that certain technological factors are of high importance for the adoption of big data technologies in cities, but are at low relative levels of performance, it is possible to conduct a deeper analysis of their aspects that need to be improved.

For the purpose of this study, IPMA was used at two levels: i) factor level - to identify whether technological factors are important for the adoption of big data technologies in EU cities and what performance they have, and ii) particle level - to identify which aspects of technological factors have relative high importance, and lower performance, i.e. have the potential for improvement through various activities and thus positively affect the success of the adoption of big data technologies in the cities of the European Union. 
The IPMA procedure was performed according to the steps proposed in Ringle and Stardsted (2016) and Hair et al. (2018). IPMA has been used in research to date to identify aspects of factors important for the adoption of various technologies and concepts, such as cloud computing (Khayer et al., 2020), mobile learning (Al-Emran and Mezhuyev, 2020), electronic commerce (Nathan et al. 2019; Magal, Kosalgei Levenburg, 2009), the hospital information system (Markazi-Maghaddam, Kazemi, and Alimoradnori, 2019), and cryptocurrency (Sohaib et al., 2020).

\section{Results}

Results of the evaluation of the model of adoption of big data technologies in the cities of the European Union

The results of the measurement and structural assessment of the model of adoption of big data technologies in the cities of the European Union are part of the published doctoral dissertation (Pivar, 2020a). For the purposes of this article, the results of the model evaluation are summarized.

The results of the assessment of the measure of reflective factors before and after solving the problem of the measurement model are shown in Table 2. Based on the Cronbach Alpha indicator for assessing the reliability of the internal consistency of factors, it is concluded that the reliability and validity of all factors is satisfactory. Namely, the values of the Cronbach's Alpha indicator are within the permitted limits for all reflectively measured factors, and the value of the average explained variance indicator for all of them is higher than 0.500 . According to the Fornell - Larcker criterion, there is no problem of discriminant validity in the model since the value of the square root of AVE of each factor is greater than its maximum correlation with any other factor.

Particle TR3 has an external load of less than 0.700 , so a decision was made to exclude it from the TR factor. Particle TR3 speaks about the respondents agree that the city has a physical ICT infrastructure that can be upgraded with big data technologies. However, this aspect is already covered to some extent in the model factor that describes the compatibility of the city's technological infrastructure so it can be excluded from the model.

\section{Table 2}

Results of evaluation of the measurement model of reflective factors

\begin{tabular}{|c|c|c|c|c|c|}
\hline \multirow[t]{2}{*}{ Factor } & \multirow[t]{2}{*}{ Particles } & $\begin{array}{c}\text { Cronbach } \\
\text { Alfa }\end{array}$ & $\begin{array}{c}\text { Average } \\
\text { explained } \\
\text { variance- } \\
\text { AVE }\end{array}$ & External loads & $\begin{array}{c}\text { Fornell- } \\
\text { Larcker } \\
\sqrt{A V E>C O R R}\end{array}$ \\
\hline & & $>0.600$ & $>0.500$ & $>0.700$ & \\
\hline \multirow{4}{*}{ TR } & TR1 & \multirow{4}{*}{$\begin{array}{l}0.813 / \\
0.810^{*}\end{array}$} & \multirow{4}{*}{$\begin{array}{c}0.877 / \\
0.726^{* *}\end{array}$} & $0.866 / 0.884^{* * *}$ & \multirow{4}{*}{ yes } \\
\hline & TR2 & & & $0.883 / 0.879^{* * *}$ & \\
\hline & TR3 & & & $\begin{array}{c}0.674 / \\
\text { excluded }\end{array}$ & \\
\hline & TR4 & & & $0.766 / 0.790^{* * *}$ & \\
\hline \multirow{4}{*}{ CM } & $\mathrm{CMl}$ & \multirow{4}{*}{0.887} & \multirow{4}{*}{0.747} & 0.824 & \multirow{4}{*}{ yes } \\
\hline & CM2 & & & 0.910 & \\
\hline & $\mathrm{CM} 3$ & & & 0.776 & \\
\hline & CM4 & & & 0.937 & \\
\hline \multirow{3}{*}{ CMS } & CMS1 & \multirow{3}{*}{0.913} & \multirow{3}{*}{0.794} & 0.882 & \multirow{3}{*}{ yes } \\
\hline & CMS2 & & & 0.938 & \\
\hline & CMS3 & & & 0.880 & \\
\hline
\end{tabular}




\begin{tabular}{|c|c|c|c|c|c|}
\hline & CMS4 & & & 0.863 & \\
\hline \multirow{4}{*}{ SCS } & SCSI & \multirow{4}{*}{0.908} & \multirow{4}{*}{0.784} & 0.879 & \multirow{4}{*}{ yes } \\
\hline & SCS2 & & & 0.887 & \\
\hline & SCS3 & & & 0.890 & \\
\hline & SCS4 & & & 0.885 & \\
\hline \multirow{4}{*}{ SS } & SS1 & \multirow{4}{*}{0.801} & \multirow{4}{*}{0.625} & 0.763 & \multirow{4}{*}{ yes } \\
\hline & SS2 & & & 0.746 & \\
\hline & SS3 & & & 0.848 & \\
\hline & SS4 & & & 0.800 & \\
\hline
\end{tabular}

*Cronbach's Alpha value after solving the measurement model problem

**the AVE value after solving the measurement model problem

***the value of external loads after solving the measurement model problem

Source: according to Pivar (2020a), using SmartPLS3 and Office 2019 software

The results of the assessment of formative factors before and after solving the problem of the measurement model are presented in Table 3.

External weights of particle factors Absorption capacity - AC1 and AC2 are not significant, but they are absolutely important given that their external load is greater than the minimum required value of 0.500 . The external weight of the AT1 factor particle The adoption of big data technologies in cities is neither absolutely nor relatively important for assessing the adoption of big data technologies in cities. In other words, collecting large amounts of data does not necessarily mean that the city adopts big data technologies. For this reason, a decision was made to exclude it from the AT factor.

According to the value of the variance of the inflation factor - VIF for formative factors, there is no problem of collinearity.

\section{Table 3}

Results of the evaluation of the measurement model of formative factors

\begin{tabular}{|c|c|c|c|c|c|c|}
\hline Factor & Particle & $\begin{array}{c}\text { External } \\
\text { weight }\end{array}$ & p-val. & $\begin{array}{c}\text { External } \\
\text { load } \\
>0,500\end{array}$ & $\begin{array}{c}\text { Importance } \\
\text { of the } \\
\text { particle }\end{array}$ & $\begin{array}{c}\text { VIF } \\
<5.000\end{array}$ \\
\hline \multirow{4}{*}{$A C$} & $\mathrm{ACl}$ & $\begin{array}{l}0.019 / \\
0.005^{i}\end{array}$ & $\begin{array}{l}0.918 / \\
0.979 i i\end{array}$ & $\begin{array}{l}0.761 / \\
0.754^{\text {iii }}\end{array}$ & absolute & 2.706 \\
\hline & AC2 & $\begin{array}{l}-0.028 / \\
-0.026 i\end{array}$ & $\begin{array}{l}0.923 / \\
0.927 i i\end{array}$ & $\begin{array}{l}0.798 / \\
0.797 \text { iii }\end{array}$ & absolute & 3.050 \\
\hline & AC3 & $\begin{array}{l}0.637 / \\
0.644 i\end{array}$ & $\begin{array}{l}0.017 / \\
0.015^{\mathrm{ii}}\end{array}$ & $\begin{array}{l}0.932 / \\
0.931 \text { iii }\end{array}$ & $\begin{array}{l}\text { absolute } \\
\text { and } \\
\text { relative }\end{array}$ & 3.168 \\
\hline & AC4 & $\begin{array}{l}0.477 / \\
0.482^{i}\end{array}$ & $\begin{array}{c}0.011 \\
10.007 \mathrm{ii}\end{array}$ & $\begin{array}{l}0.868 / \\
0.869 \text { iii }\end{array}$ & $\begin{array}{l}\text { absolute } \\
\text { and } \\
\text { relative }\end{array}$ & 2.256 \\
\hline \multirow{4}{*}{ AT } & ATI & $\begin{array}{c}-0.020 / \\
n / a^{i}\end{array}$ & $\begin{array}{c}0.833 / \\
n / a^{i i}\end{array}$ & $\begin{array}{c}0.443 / \\
\mathrm{n} / \mathrm{a} \text { iii }\end{array}$ & excluded & $\begin{array}{c}1.311 / \\
\mathrm{n} / \mathrm{a}^{\mathrm{iv}}\end{array}$ \\
\hline & AT2 & $\begin{array}{l}0.540 / \\
0.517^{i}\end{array}$ & $\begin{array}{l}0.000 / \\
0.000^{\mathrm{ii}}\end{array}$ & $\begin{array}{l}0.942 / \\
0.939 \text { iii }\end{array}$ & $\begin{array}{l}\text { absolute } \\
\text { and } \\
\text { relative }\end{array}$ & $\begin{array}{l}2.815 / \\
2.518^{\text {iv }}\end{array}$ \\
\hline & AT3 & $\begin{array}{l}0.258 / \\
0.269 i\end{array}$ & $\begin{array}{l}0.043 / \\
0.034\end{array}$ & $\begin{array}{l}0.895 / \\
0.899 \text { iii }\end{array}$ & $\begin{array}{l}\text { absolute } \\
\text { and } \\
\text { relative }\end{array}$ & $\begin{array}{l}3.440 / 1 \\
3.431 \mathrm{iv}\end{array}$ \\
\hline & AT4 & $\begin{array}{l}0.299 / \\
0.302^{i}\end{array}$ & $\begin{array}{l}0.016 / \\
0.016 \mathrm{ii}\end{array}$ & $\begin{array}{l}0.900 / \\
0.902 \text { iii }\end{array}$ & $\begin{array}{l}\text { absolute } \\
\text { and } \\
\text { relative }\end{array}$ & $\begin{array}{l}3.364 \text { / } \\
3.357^{\mathrm{iv}}\end{array}$ \\
\hline
\end{tabular}

${ }^{i}$ external weight after solving the measurement model problem 


\footnotetext{
ii $p$-value after solving the measurement model problem

iii external load after solving the measurement model problem

iv VIF after solving the measurement model problem
}

Source: according to Pivar (2020a), using SmartPLS3 and Office 2019 software

Table 4 shows the results of the structural model assessment. With a confidence level of $10 \%$, it has been proven that technological factors absorption capacity $(A C \rightarrow A T$, path coefficient 0.216, p-value 0.069) and technological readiness (TR $\rightarrow$ AT, path coefficient 0.191 , p-value 0.052 ) have a positive effect on the adoption of big data technology in cities.

According to the values of the coefficient of determination and the adjusted coefficient of determination, the proposed factors of adoption of big data technologies in cities explain a satisfactory amount of variance in the adoption of big data technologies in cities.

\section{Table 4}

Results of structural model assessment

\begin{tabular}{lcl}
\hline \multicolumn{1}{c}{ Impact } & Path coefficient & p.-val. \\
\hline AC $\rightarrow$ AT & 0.216 & $0.069^{* * *}$ \\
\hline TR $\rightarrow$ AT & 0.191 & $0.052^{* * *}$ \\
\hline $\mathrm{CM} \rightarrow$ AT & -0.131 & 0.132 \\
\hline SS $\rightarrow$ AT & 0.271 & $0.000^{*}$ \\
\hline $\mathrm{CMS} \rightarrow$ AT & 0.184 & $0.085^{* * *}$ \\
\hline SCS $\rightarrow$ AT & 0.279 & $0.012^{* *}$ \\
\hline \multicolumn{1}{r}{$\boldsymbol{R}^{2}$} & 0.791 & \\
\hline Adapted $\mathbf{R}^{2}$ & 0.770 & \\
\hline
\end{tabular}

\footnotetext{
* statistically significant with $1 \%$

** statistically significant with $5 \%$

*** statistically significant with $10 \%$
}

Source: according to Pivar (2020a), using SmartPLS3 and Office 2019 software

\section{Results of importance and performance analysis}

A prerequisite for the analysis of the importance and performance of technological factors is to prove the hypotheses of the model of adoption of big data technologies in the cities of the European Union. Hypotheses $\mathrm{H} 1 \mathrm{a}$ and $\mathrm{H} 1 \mathrm{~b}$ were supported, i.e. absorption capacity and technological readiness were shown to have a positive effect on the adoption of big data technology in cities. Compatibility does not have a significant impact on the adoption of big data technology in cities and is therefore omitted from further interpretation of the analysis results.

\section{Analysis of importance and performance at the factor level}

The results of IPMA are presented below. All values are calculated with the support of specialized SmartPLS3 software. Table 7 lists the values of importance and performance of factors that have been shown to affect the target AT factor significantly. The average of importance and performance was calculated so that the lines for dividing the map into 4 segments could be drawn on the map of importance and performance.

\section{Table 5}

Values of importance and performance of factors of adoption of big data technologies in the cities of the European Union ( $\mathrm{N}=67)$ 


\begin{tabular}{lrr}
\hline Factor & Importance & Performance \\
\hline AC & 0.216 & 64.034 \\
\hline TR & 0.191 & 61.833 \\
\hline CM & -0.131 & 57.672 \\
\hline CMS & 0.184 & 65.733 \\
\hline SCS & 0.278 & 72.201 \\
\hline SS & 0.271 & 63.468 \\
\hline Average & 0.168 & 64.157 \\
\hline
\end{tabular}

Source: author, using SmartPLS3 and Office 2019 software

The map of importance and performance factors (Figure 1) shows the values of the overall effects, i.e. the importance of factors that indicate that the highest importance for the performance of the adoption of big data technologies in cities is the existence of a smart city strategy. The maps suggest that stakeholder support has the most potential for improvement and impact on the adoption of big data technologies. Namely, stakeholder support has a relatively low performance, but a very high overall impact on the adoption of big data technologies in the cities of the European Union. Regarding technological factors, cities can think about how to improve their absorption capacity and technological readiness in order to support the adoption of big data technologies. It can be seen that both factors are of relatively low performance, while the importance of absorption capacity is relatively greater than technological readiness. Strengthening both factors would increase the success or performance of the adoption of big data technologies in the cities of the European Union.

\section{Figure 1}

Map of the importance and performance of big data technology adoption factors in European Union cities

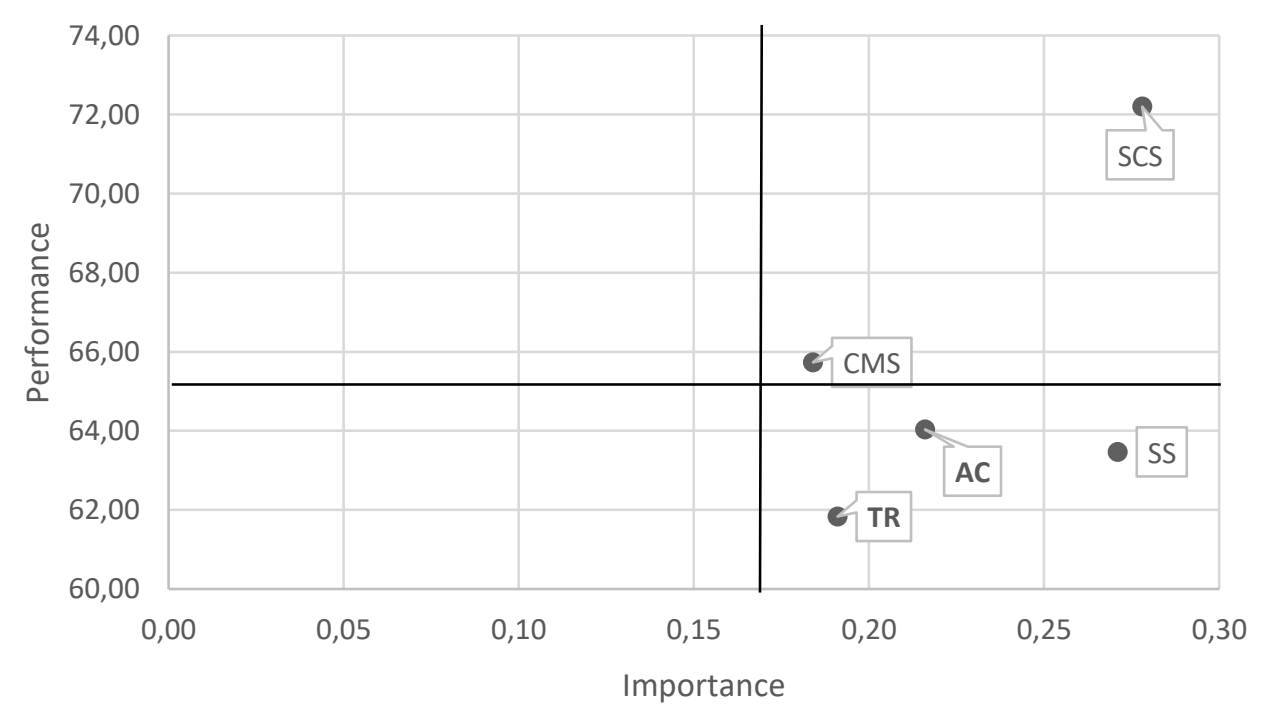

Source: author, using SmartPLS3 and Office 2019 software

Analysis of importance and performance at the particle level 
Table 8 shows the values of importance and particle performance of all factors. In the following, for the purposes of interpreting the IPMA results, the particles will be referred to as factor aspects.

The average of importance and performance was also calculated so that the lines for dividing the map into 4 segments could be drawn on the map of importance and performance.

\section{Table 6}

Values of importance and performance aspects of big data technology adoption factors in European Union cities $(\mathrm{N}=67)$

\begin{tabular}{lrr}
\hline Aspect & Importance & Performance \\
\hline AC1 & 0.001 & 66.915 \\
\hline AC2 & -0.006 & 66.169 \\
\hline AC3 & 0.139 & 61.194 \\
\hline AC4 & 0.104 & 67.910 \\
\hline TR1 & 0.079 & 55.970 \\
\hline TR2 & 0.073 & 61.443 \\
\hline TR4 & 0.072 & 67.164 \\
\hline CM1 & -0.033 & 55.970 \\
\hline CM2 & -0.041 & 54.975 \\
\hline CM3 & -0.027 & 64.677 \\
\hline CM4 & -0.048 & 57.214 \\
\hline CMS1 & 0.050 & 72.886 \\
\hline CMS2 & 0.052 & 68.657 \\
\hline CMS3 & 0.054 & 58.955 \\
\hline CMS4 & 0.051 & 61.940 \\
\hline SCS1 & 0.075 & 74.876 \\
\hline SCS2 & 0.075 & 72.139 \\
\hline SCS3 & 0.082 & 71.891 \\
\hline SCS4 & 0.082 & 70.149 \\
\hline SS1 & 0.100 & 66.418 \\
\hline SS2 & 0.069 & 65.174 \\
\hline SS3 & 0.097 & 60.199 \\
\hline SS4 & 0.077 & 61.940 \\
\hline Average & 0.044 & 64.794 \\
\hline
\end{tabular}

Source: author, using SmartPLS3 and Office 2019 software

The map of importance and performance of particles (Figure 2) suggests that among technological factors, aspects of AC3, TR1 and TR2 have the most potential to improve the adoption of big data technologies in smart cities.

Of the technological factors, the aspect of knowledge absorption by employees has the greatest potential for improvement (AC3). This means that the adoption of big data technologies in EU cities can be more successful if city employees increase the absorption of new knowledge, link existing knowledge with new knowledge, use such knowledge in practical work and make it available for future use. The city can positively influence the adoption of big data technologies in the city by strengthening the TR1 aspect that describes the analytical skills of employees. This would mean that cities should strive to employ human resources that possess analytical skills, including data mining skills and knowledge of data processing methodology, data integration, and data management. Also, the city 
should employ people who have IT skills and skills in using programming languages, technologies and programs such as Excel, SAS, SPSS, R programming language, Java, visualization tools, SQL databases, noSQL databases and Hadoop solutions, which are an integral part of big data technologies (aspect TR2).

Figure 2

Map of the importance and performance aspects of the factors of adoption of big data technologies in the cities of the European Union

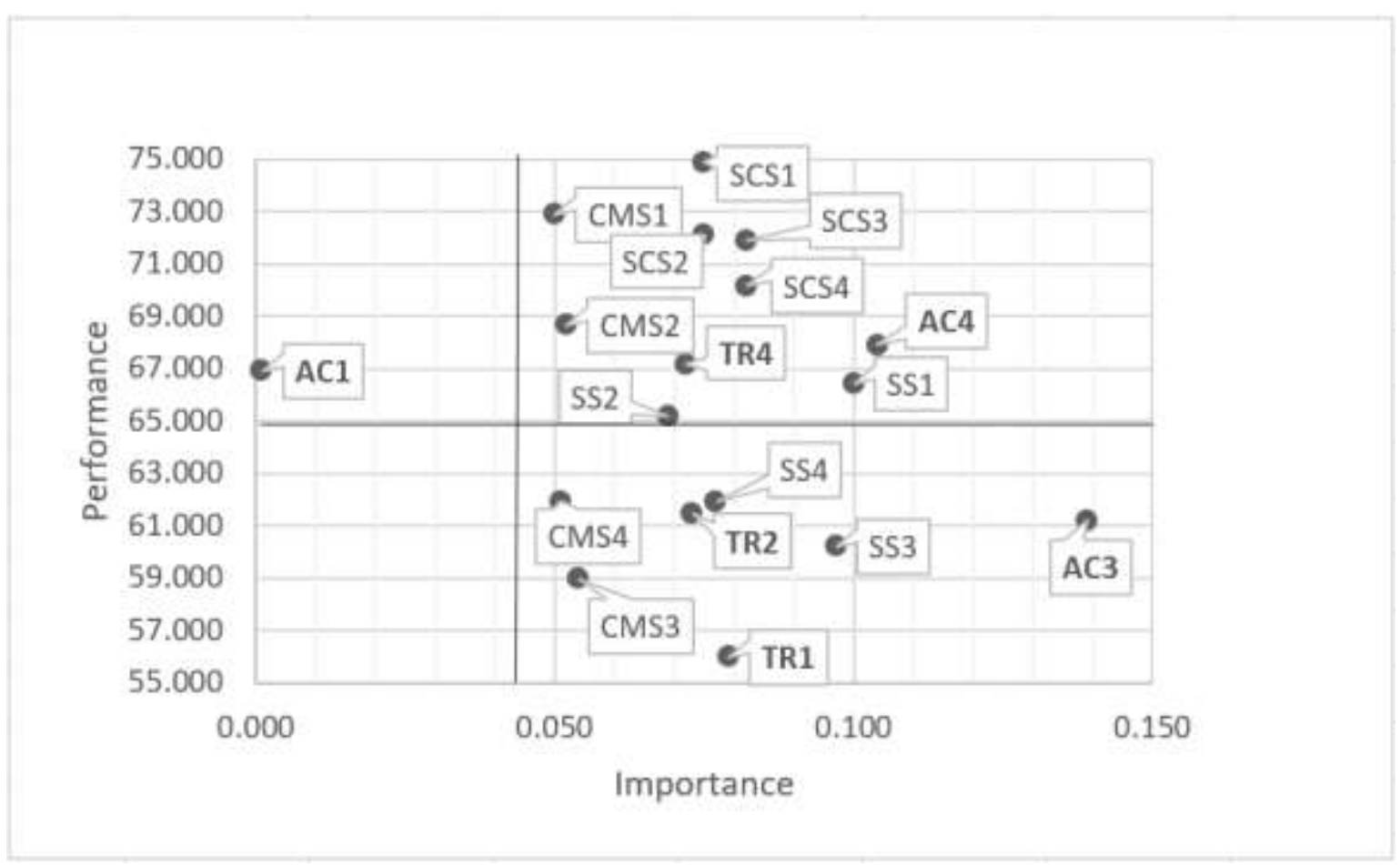

Source: author, using SmartPLS3 and Office 2019 software

\section{Discussion}

The research findings showed that the technological readiness of the city and the absorption capacity of the city are important for the adoption of big data technologies in cities. Existing research is in line with these findings. Organizations that have developed aspects of technological readiness are more successful in adopting various information and communication technologies important for the development of smart cities. For example, business intelligence and knowledge management systems (Bhatiasevi and Naglis, 2020; Lautenbach, Johnston and Adeniran Ogundipe, 2017), cloud computing (Hassan et al., 2017, Hossain, Standing, \& Chan, 2017) and the Internet of Things (Ching-Wen and ChingChiang, 2017). Furthermore, absorption capacity positively influences the adoption of information and communication technologies such as RFID technology, which is important for smart cities (Weia, Lowry and Seedorf, 2015).

The impact of compatibility on the adoption of big data technologies has not been proven. This is consistent with some studies in which it has been observed in the context of some other technologies such as RFID technology (Thiesse et al., 2011) and cloud computing (Gutierrez, Boukrami, and Lumsden, 2015). 
An important part of the city's technological readiness is the awareness of the city management about the costs and benefits of investing in technology and available financial resources. The city is technologically ready if the financial aspect of disposing of financial resources for upgrading the city with information and communication technologies is met. These aspects of the city's technological readiness for the analysis of importance and performance are relatively important, but also at relatively high performance.

The absorption capacity of the average European Union city is low. City departments are often unaware of the importance of mutual communication in solving problems related to city services and infrastructure, and the importance of rapid mutual flow of information. City employees find it difficult to absorb new knowledge related to new technologies and associate it poorly with existing knowledge. Therefore, they are used to a lesser extent in practical work. Nevertheless, there is an awareness in the city of the existence of new technologies and their introduction is being considered in order to increase the efficiency of the services of the city. It is recommended that the cities consider how to motivate employees and improve the absorption capacity of the city in order to support the adoption of big data technologies in cities.

City management could support strengthening the absorption capacity of their city by increasing the level of technological readiness of the city. Namely, the average European Union city to a lesser extent has employees with analytical and IT skills that include data management skills. Employing human resources that possess data management skills would also increase the absorption capacity of the city to adopt advanced information and communication technologies such as big data technology.

According to the approach of the Quality Management System, it is possible to create a framework for a smart city development program. An example of a smart city development program framework is presented and explained in Borsboom-van Beurden, Kallaos, Gindroz, Costa, and Riegler (2016). According to this framework, the development of a smart city goes through phases of defining the vision, ensuring political commitment of all stakeholders, planning the implementation of activities, implementation of plans, monitoring and evaluating the implementation of plans, acting on evaluation results and finally replicating and re-applying good practices. Technological factors can therefore be linked to the phases of the smart city development program framework, i.e. the results of the analysis can be brought closer to the city management and other cities using the well-known concept of continuous improvement and quality management system.

It is a general recommendation that cities, depending on the stage of development of the smart city, pay special attention to certain phases of the framework of the smart city development program.

Cities just moving towards smart city development need to pay special attention to the stages of vision creation, political commitment and planning to begin with. These phases are important for achieving a higher level of smart city maturity as they provide the prerequisites and favourable levels of factors for the adoption of advanced information and communication technologies such as big data technologies. Therefore, cities that are just at the beginning of the development of a smart city must provide favourable conditions for the implementation of smart initiatives, and thus the adoption of innovative information and communication technologies. Among them is the achievement of a satisfactory level of technological prerequisites, i.e. technological readiness and absorption capacity of the city.

Smart cities that have not adopted big data technology can, based on monitoring and assessment of the state of infrastructure, be directed to planning big data technology adoption projects. It is assumed that they have provided a certain level of technological factors for the needs of existing projects. However, it is especially important to strengthen 
the absorption capacity and technological readiness of the city in order to be able to adopt big data technologies.

Cities adopting big data technologies generally have a high level of absorption capacity and technological readiness. They should monitor and assess the impact of the adoption of big data technologies on cities and adjust plans as necessary. Cities that have successfully implemented big data technology adoption projects in cities can disseminate their knowledge and set a good example to other cities. For them, fine-tuning of aspects of technological readiness and absorption capacity for future potential adoption of various innovative information communication technologies related to big data technologies is possible.

Thus, the recommendation to cities is to assess and ensure the necessary aspects of technological readiness and absorption capacity at the beginning of their development towards a smart city. Technological readiness and absorption capacity need to be continuously improved through later stages in order to achieve a higher level of smart city maturity. In this way, the city will meet the prerequisites and ensure the success of the adoption of big data technologies.

\section{Conclusion}

This research identifies important technological factors and their aspects for the adoption of big data technologies in the cities of the European Union. In order to analyse the importance and performance of each factor for the adoption of big data technologies in the cities of the European Union, it was necessary to conduct an assessment of the main research model of the adoption of big data technologies in the cities of the European Union. The results of the evaluation of the research model are the basis of the analysis conducted for the purpose of this paper. The model was estimated on the basis of data collected by a survey questionnaire on a sample of European Union cities. The results of the research show that the absorption capacity and technological readiness of cities influence the adoption of big data technologies in cities, but their existing performance for the average European city is low. The paper provides general guidelines for increasing the level of technological readiness and absorption capacity of cities in order to increase the success of the adoption of big data technologies in the cities of the European Union. In this way, the goal of the research was fulfilled.

The scientific contribution of this paper is reflected in the application of the PLS-SEM and IPMA methods to explain the adoption of big data technologies in the cities of the European Union. The practical contribution is reflected in the general recommendations to cities regarding significant technological factors.

A limitation of this research is the generality of recommendations for cities that are not at the same levels of smart city maturity. In order to overcome this limitation, it is necessary to introduce categories of cities according to the maturity of the smart city and then to give recommendations for each city category on which factors and aspects of factors need attention and initiate activities to increase the success of technology adoption in cities. In future research, it is necessary to combine the findings of the analysis of importance and performance with the findings related to organizational and environmental factors.

\section{References}

Abdollahzadehgan, A. et al. (2013). The Organizational Critical Success Factors for Adopting Cloud Computing in SMEs. Journal of information systems research and innovation, 67-64. 
Al-Emran M., Mezhuyev V. (2020) Examining the Effect of Knowledge Management Factors on Mobile Learning Adoption Through the Use of Importance-Performance Map Analysis (IPMA). U: Hassanien A., Shaalan K., Tolba M. (Eds.), Proceedings of the International Conference on Advanced Intelligent Systems and Informatics 2019. AlSI 2019. Advances in Intelligent Systems and Computing, vol 1058. (str. 449-458). Springer, Cham.

Angelidou, M. (2014). Smart city policies: A spatial approach. Cities, 41, 3-11.

Bettencourt, L.M.A. (2014). The Uses of Big Data in Cities. Mary Ann Liebert, INC., 2(1), 111.

Bhatiasevi, V., Naglis, M. (2020). Elucidating the determinants of business intelligence adoption and organizational performance. Information Development, 36(1), 78-96.

Bhattacherjee, A., Hikmet, N. (2008). Reconceptualizing organizational support Reconceptualizing Organizational Support and its Effect on Information Technology Usage: Evidence from the Health Care Sector. Journal of Computer Information Systems, 48(4), 69-76.

Bolívar, M. P. (2015) Smart Cities: Big Cities, Complex Governance? U: Bolívar, R., Pedro, M., ur. Transforming City Governments for Successful Smart Cities. Springer International Publishing, 1-7.

Borsboom-van Beurden et al. (2016). Smart City Guidance Package - A Roadmap for Integrated Planning and Implementation of Smart City Projects. EIP-SCC. https://eusmartcities.eu/sites/default/files/2019-

07/Smart\%20City\%20Guidance\%20Package\%20LowRes\%201v22\%20\%28002\%29 0.pd $\mathrm{f}$

Cegielski, C.G., Jia, L., Hall, D.J. (2018). Understanding the Factors Affecting the Organizational Adoption of Big Data. Journal of computer information systems, 58(3), 193203.

Chen, D.Q., Preston, D.S., Swink, M. (2015). How the Use of Big Data Analytics Affects Value Creation in Supply Chain Management. Journal of Management Information Systems, 32(4), 4-39.

Ching-Wen, H., Ching-Chiang, Y. (2017). Understanding the factors affecting the adoption of the Internet of Things. Technology Analysis \& Strategic Management, 29(9), 1089-1102.

Chong, A.Y.-L., Chan, F.T.S. (2012). Structural equation modeling for multi-stage analysis on Radio Frequency Identification (RFID) diffusion in the health care industry. Expert Systems with Applications, 39(2012), 8645-8654.

Cohen, W.M., Levinthal D.A. (1990). Absorptive capacity: A new perspective on learning and innovation. Administrative Science Quarterly, 35(1), 128-152.

Dedrick, J. et al. (2015). Adoption of smart grid technologies by electric utilities: factors influencing organizational innovation in a regulated environment. Electronic Markets, 25(1), 17-29.

Flatten, T.C. et al. (2011). A measure of absorptive capacity: Scale developmentand validation. European Management Journal, 29(2), 98-116.

Gangwar, H., Date, H., Ramaswamy, R. (2014). Understanding determinants of cloud computing adoption using an integrated TAM TOE MODEL. Journal of Enterprise Information Management, 28 (1), 107-130. 
Gutierrez, A., Boukrami, E., Lumsden, R. (2015). Technological, organisational and environmental factors influencing managers' decision to adopt cloud computing in the UK. Journal of Enterprise Information Management, 28 (6), 788-807.

Hair, J.F. et al. (2017). A primer on partial least squares structural equation modeling (PLS$S E M)$. Los Angeles, SAD: SAGE Publications.

Hair, J.F. jr. et al. (2018). Advanced issues in partial least squares structural equation modelling. Thousand Oaks, CA: SAGE Publications, Inc.

Hashem, I. A. T. et al. (2016). The role of big data in smart city. International Journal of Information Management, 36, 748-758.

Hassan, H. et al. (2017). Factors influencing cloud computing adoption in small and medium enterprises. Journal of Information and Communication Technology (JICT), 1, 21-41.

Hossain, M., Standing, C., Chan, C. (2017). The development and validation of a twostaged adoption model of RFID technology in livestock businesses. Information Technology \& People, 30(4), 785-808.

ITU-T Focus Group on Smart Sustainable Cities (2015). Setting the stage for stakeholders' engagement in smart sustainable cities. http://www.itu.int/en/ITUT/focusgroups/ssc/Pages/default.aspx[10.prosinca, 2015.]

Khayer, A., Jahan, N., Hossain, M.N., Hossain, M.Y. (2020). The adoption of cloud computing in small and medium enterprises: a developing country perspective. VINE Journal of Information and Knowledge Management Systems, Vol. ahead-of-print No. ahead-of-print. https://doi.org/10.1108/VJIKMS-05-2019-0064

Lai, Y.Y., Sun, H.F., Ren, J.F. (2018). Understanding the determinants of big data analytics (BDA) adoption in logistics and supply chain management: An empirical investigation. International Journal of Logistics Management, 29(2), 676-703.

Lautenbach, P., Johnston, K., Adeniran-Ogundipe, T. (2017). Factors influencing business intelligence and analytics usage extent in South African organisations. South African Journal of Business Management, 48(3), 23-33.

Magal, S.R., Kosalge, P., Levenburg, N.M. (2009). Using importance performance analysis to understand and guide e-business decision making in SMEs. Journal of Enterprise Information Management, 22(1/2), 137-151.

Markazi-Moghaddam, N., Kazemi, A., Alimoradnori, M. (2019). Informatics in Medicine Unlocked, 17, 100251. https://doi.org/10.1016/j.imu.2019.100251.

Nathan, R.J., Victor, V., Gan, C.L., Kot, S. (2019). Electronic commerce for home-based businesses in emerging and developed economy. Eurasian Business Review, 9, 463-483.

Neirotti, P. et al. (2014). Current trends in Smart City initiatives: Some stylized facts. Cities, $38,25-36$.

Sohaib, W., Hussain, M., Asif, M., Ahmad, M., Mazzara, M. (2020). A PLS-SEM Neural Network Approach for Understanding Cryptocurrency Adoption. IEEE Access, 8, 1313813150.

Odbor Europskog parlamenta za industriju, istraživanje i energetiku - ITRE (2014). Mapping Smart Cities in the EU. Brusseles: European Parliament, Directorate General for internal policies. https://www.europarl.europa.eu/RegData/etudes/etudes/join/2014/507480/IPOLITRE_ET(2014)507480_EN.pdf 
Oliveira, T., Manoj, T., Espadanal, M. (2014). Assessing the determinants of cloud computing adoption: An analysis of the manufacturing and services sectors. Information \& Management, 51(2014), str. 497-510.

Pejić Bach, M., Bertoncel, T., Meško, M., Suša Vugec, D., Ivančić, L. (2020). Big Data Usage in European Countries: Cluster Analysis Approach. Data, 5(1), 25.

Pejić Bach, M., Krstić, Ž., Seljan, S., Turulja, L. (2019). Text mining for big data analysis in financial sector: A literature review. Sustainability, 11(5), 1277.

Pejić Bach, M., Pivar, J., Krstić, Ž. (2019) Big Data for Prediction: Patent Analysis Patenting Big Data for Prediction Analysis. U: Strydom, M. J., Strydom, K., Beverley, S. (Ed.), Big Data Governance and Perspectives in Knowledge Management (str. 218-240). Hershey Pennsylvania: IGI Global.

Pivar, J. (2020a). Model usvajanja tehnologija velikih podataka u pametnim gradovima Europske Unije (urn:nbn:hr:148:687894). [Disertacija, Sveučilište u Zagrebu, Ekonomski fakultet]. Repozitorij radova Ekonomskog fakulteta Zagreb - REPEFZG.

Pivar, J. (2020b) City Management Support And Smart City Strategy as Success Factors in Adopting Big Data Technologies for Smart Cities. U: Drezgić, S., Žišković, S., Tomljanović, M. (Eds.), Smart Governments, Regions and Cities Research monograph - First Edition (str. 167- 183).

Pivar, J. i Vlahović, N. (2020) Stakeholder Support as Critical Success Factor in Adopting Big Data Technologies for Smart Cities. U: Skala, K. (Eds.), Proceedings of the 43nd International Convention on Information and Communication Technology, Electronics and Microelectronics MIPRO 2020 (pp. 2153-2158). Opatija: Croatian Society for Information and Communication Technology, Electronics and Microelectronics - MIPRO.

Ringle, C.M., Sarstedt, M. (2016). Gain more insight from your PLS-SEM results: The importance-performance map analysis. Industrial Management \& Data Systems, 116(9), 1865-1886.

Rogers, E. M. (2003). Diffusion of Innovations. 5thEdition. New York: Free Press.

Rouhani, S. et al. (2018). Business Intelligence Systems Adoption Model; An Empirical Investigation. Journal of Organizational and End User Computing, 30(2), 43-70.

Sambamurthy, V., Bharadwaj, A., Grover, V. (2003). Shaping Agility through Digital Options: Reconceptualizing the Role of Information Technology in Contemporary Firms, MIS Quarterly, 27(2), 237-263.

Tan, J., Tyler, K. i Manica, A. (2007). Business-to-business adoption of e-commerce in China. Information \& Management, 44 (3), 332-351.

Thiesse, F. et al. (2011). The rise of the "next-generation bar code": an international RFID adoption study. Supply Chain Manage.: Int. J.,16, 245-328

Tomičić Furjan, M., Tomičić-Pupek, K., Pihir, I. (2020). Understanding Digital Transformation Initiatives: Case Studies Analysis. Business Systems Research, 11(1), 125141.

Tornatzky, L.G., Fleischer, M., Chakrabarti, A. K. (1990). The Processes of Technological Innovation. Massachusetts: Lexington Books.

Tsai, W.-C., Tang, L.-L. (2012). A model of the adoption of radio frequency identification technology: The case of logistics service firms. Journal of Engineering and Technology Management, 29(1), 131-151. 
Wang, Y.-M., Wang, Y.-S., Yang Y.-F. (2010). Understanding the determinants of RFID adoption in the manufacturing industry. Technologial Forecasting \& Social Change, 77(2010), 803-815.

Wang, H.-J., Lo, J. (2016). Adoption of open government data among government agencies. Government Information Quarterly, 33(1), 80-88.

Weia, J., Lowry, P.B., Seedorf, S. (2015). The assimilation of RFID technology by Chinese companies: A technology diffusion perspective. Information \& Management, 52(6), 628642.

Zhu, K., Kraemer, K.L., Xu, S. (2006). The process of innovation assimilation by firms in different countries: a technology diffusion perspective on e-business. Manage. Sci., 52, 1557-1576.

\section{About the author}

Jasmina Pivar is currently employed as an assistant at the Department of Informatics at the Faculty of Economics and Business - Zagreb. She holds a PhD in economics from the Faculty of Economics and Business - Zagreb with a doctoral dissertation entitled "Adoption of big data technologies in smart cities of the European Union". She completed her graduate studies at the Jasmina Pivar is currently employed as an assistant at the Department of Informatics at the Faculty of Economics - Zagreb. She holds a PhD in economics from the Faculty of Economics - Zagreb with a doctoral dissertation entitled "Adoption of big data technologies in smart cities of the European Union". She completed her graduate studies at the Faculty of Organization and Informatics in Varaždin. Her main research interests are big data, smart cities, data mining, Internet of Things, and technology adoption. The author can be contacted at jpivar@efzg.hr 